\title{
MENCETAK GENERASI ANAK USIA DINI YANG BERJIWA QUR'ANI DALAM PERSPEKTIF PENDIDIKAN AGAMA ISLAM
}

\author{
Eka Wahyu Hidayati ${ }^{\text {a, } 1}$ \\ ${ }^{a}$ Sekolah Tinggi Agama Islam Daruttaqwa Gresik \\ ${ }^{1}$ ekawahyu@staidagresik.ac.id
}

\begin{tabular}{l}
\hline Informasi artikel \\
\hline Received: \\
Agust 11, 2019. \\
Revised: \\
Agust 27, 2019. \\
Publish: \\
September 09, 2019. \\
Kata kunci: \\
Generasi Al Qur'an; \\
Anak Usia Dini; \\
Pendidikan Agama \\
Islam;
\end{tabular}

Keywords:

Qur'an generation;

Early childhood;

Islamic education;

\begin{abstract}
ABSTRAK
Al Qur'an adalah sumber segala ilmu. Baik itu ilmu umum, maupun ilmu agama. Anak usia dini sebagai generasi yang berjiwa qur'ani akan membuat pendidikan menjadi lebih baik. Penelitian ini menggunakan model kualitatif deskriptif dalam bentuk library research dengan metode dokumentasi. Tujuan penelitian ini yaitu untuk mengetahui generasi anak usia dini yang berjiwa qur'ani dan perspektif pendidikan agama Islam. Hasil dari penelitian ini yaitu generasi anak usia dini qur'ani adalah generasi yang menjaga ayat-ayat Allah dihatinya, yang memiliki kepribadian Qur'ani, yang mengambil Al-Qur'an sebagai sumber utama kehidupannya melalui membaca, mempelajari, memahami dan mengamalkan Al Qur'an dalam setiap aspek kehidupan. Kedua yaitu dalam perspektif Pendidikan Agama Islam yaitu: dengan membangun kepribadian Qur'ani sejak dini dengan cara antara lain: membangun rasa cinta pada Al-Qur'an, memperdengarkan lantunan ayat Al Qur'an one day one juz, menumbuhkan mujahadah takwa kepada Allah, tadabbur Al-Qur'an, mengatasi rasa malas berinteraksi dengan Al-Quran, serta menyampaikan isi Al-Qur'an.
\end{abstract} the full texts of its articles and allow readers to use them for any other lawful purpose. 


\section{PENDAHULUAN}

Rasulullah SAW bersabda: "Siapa yang mempelajari al-Qur'an ketika masih muda, maka al-Quran itu akan menyatu dengan daging dan darahnya. Siapa yang mempelajarinya ketika dewasa, sedangkan ilmu itu akan lepas darinya dan tidak melekat pada dirinya, maka ia mendapatkan pahala dua kali’.

Rasulullah SAW bersabda: "barang siapa yang membaca Al Quran, mempelajarinya dan mengamalkannya, maka pada hari kiamat nanti kedua orang tuanya akan disematkan mahkota yang sinarnya lebih bagus dari sinar matahari. Dan kedua orang tuanya diberi pakaian yang tidak pernah dipakai selama hidup di dunia. Kedua orang tua itu bertanya-tanya, "mengapa diberi pakaian seperti ini?" maka dijawab "ini karena engkau berdua telah mengajarkan Al-Qur'an kepada anakmu" (Rouf, 2015).

Sebab itu, sangat penting mendidik manusia dengan pendidikan agama yang bermuara pada kalamullah. Barulah setelah itu dapat mencetak generasi yang betulbetul Qur'ani, yaitu masyarakat yang anggotanya terdiri dari orang-orang yang merupakan penjelmaan Al-Quran dalam setiap gerak kehidupannya. Masyarakat yang diasuh dan dibimbing dengan arahan Al-Quran, hidup di bawah naungannya, dan berjalan di bawah cahayanya. Bahkan memahami Al-Qur'an adalah wajib berdasarkan ayat berikut: "Maka mengapakah mereka tidak mau mentadabburi alQur'an? Apakah karena hati mereka terkunci mati?" (Rouf, 2015).

Dari uraian di atas dapat kita simpulkan bahwa kita diperintahkan utuk mempersiapkan generasi yang kuat, yang punya bekal yang cukup untuk menghadapi tantangan hidup kedepannya. Bekal yang dimaksud disini bukan sekedar harta semata, tetapi lebih mempunyai wawasan yang luas, dan yang paling penting selalu 
berpegang teguh kepada Al-Qur'an dalam menyelesaikan setiap permasalan yang terjadi.

Mencetak berarti menghasilkan sesuatu dengan usaha-usaha tertentu. Mencetak yang dimaksudkan disini adalah menghasilkan generasi dengan usaha-usaha tertentu seperti mendidik, mengarahkan, membimbing, membina manusia untuk memiliki jiwa qur'ani. Membicarakan tentang manusia, makhluk berjiwa, berkepribadian, dan berhati nurani, selalu menarik. Oleh karena itu, baik pembicaraan mengenai aspek luar (fisik) maupun aspek dalam dari diri manusia, seperti jiwa dan hati, tidak pernah selesai

Berpijak pada uraian diatas, penulis tertarik untuk mengetahui lebih jauh tentang generasi berjiwa qur'ani dalam perspektif pendidikan agama Islam. Selanjutnya topik ini dirumuskan dalam sebuah penelitian yang berjudul "Mencetak Generasi Anak Usia Dini Yang Berjiwa Qur'ani dalam Perspektif Pendidikan Agama Islam”.

\section{METODE}

Penelitian ini merupakan penelitian kualitatif. Penelitian ini menggunakan model kualitatif jenis deskriptif dalam bentuk library research dengan metode dokumentasi, sehingga tidak akan menarik suatu kesimpulan yang berlaku secara umum. Fokus penelitian ini yaitu generasi anak usia dini yang berjiwa qur'ani dan perspektif pendidikan agama Islam. 


\section{HASIL DAN PEMBAHASAN}

\section{Minat Belajar Anak Usia Dini}

Tiga jalur Pendidikan yaitu pendidikan formal, pendidikan nonformal, dan pendidikan informal. Pendidikan formal dalam hal ini diadakan oleh lembaga yang bernama sekolah. Sekolah merupakan tempat anak untuk menuntut ilmu dan pengetahuan yang akan berguna bagi kehidupannya di masa yang akan datang. Keberhasilan sekolah dalam menyelenggarakan pendidikan dapat dilihat dari berbagai hal, salah satunya adalah dalam hal minat belajar anak usia dini pada al Quran. Minat belajar adalah suatu bukti usaha anak dalam melakukan kegiatan belajarnya. Minat merupakan kemampuan seseorang untuk memberikan perhati-an terhadap suatu hal yang disertai dengan rasa senang dan dilakukan penuh kesadaran. Anak yang menaruh minat pada suatu mata pelajaran, perhatiannya akan tinggi dan minatnya berfungsi sebagai pendorong kuat untuk terlibat secara aktif dalam kegiatan belajar mengajar pada pelajaran tersebut.

Minat belajar anak usia dini pada al Quran secara garis besar dipengaruhi oleh dua faktor yaitu faktor internal dan faktor eksternal. Faktor-faktor internal yang berasal dari dalam diri anak meliputi: faktor jasmaniah (terdiri dari faktor kesehatan dan cacat tubuh), faktor psikologi (terdiri atas intelegensi, perhatian, minat, bakat, motivasi, persepsi, kematangan dan kesiapan) dan faktor kelelahan. Sedangkan faktor eksternal yang berasal dari luar diri anak meliputi: faktor keluarga yaitu cara orang tua mendidik, relasi antar anggota keluarga, suasana rumah, keadaan ekonomi keluarga, pengertian orang tua, latar belakang kebudayaan, faktor sekolah yaitu metode mengajar, kurikulum, hubungan guru dengan anak, hubungan anak dengan anak, disiplin sekolah, media pembelajaran, waktu sekolah, keadaan gedung, metode 
belajar dan tugas rumah; faktor masyarakat yaitu kegiatan anak dalam masyarakat, media, teman bergaul, dan bentuk kehidupan masyarakat.

Salah satu faktor eksternal yang mempengaruhi minat belajar anak usia dini pada al Quran adalah melalui pembiasaan sebagai kegiatan di luar kelas yang merupakan perluasan dari tugas di kelas". Pembiasaan merupakan salah satu aspek mengajar yang paling luas digunakan oleh guru. Di sisi lain, anak seringkali menganggap pembiasaan di Rumah sebagai beban mereka. Pembiasaan di rumah dapat dirancang dengan maksud meningkatkan minat belajar anak, nantinya akan meningkat dan menguasai materi anak bertambah dengan diharuskannya anak untuk mengerjakan tugas yang telah diberikan oleh guru (Reynolds, 2017).

Faktor internal yang berpengaruh pada minat belajarsalah satunya adalah minat belajar. "Minat Belajar merupakan keinginan yang datang dari hati nurani untuk ikut serta dalam kegiatan belajar". Dalam proses belajar, minat memegang peranan penting bagi prestasi belajar yang akan diperoleh anak. Seorang anak akan memperhatikan apa yang diterangkan oleh guru dan mengerjakan tugas yang diberikan jika dia mempunyai minat untuk belajar pada mata pelajaran tertentu. "Minat belajar yang besar cenderung menghasilkan prestasi yang tinggi, sebaliknya minat belajar kurang akan menghasilkan prestasi yang rendah” (Suprijanto, 2015).

Beberapa sekolah bertujuan untuk dapat menyelenggarakan suatu pendidikan yang baik dan berhasil mencetak lulusan yang berkualitas. Keberhasilan sekolah dalam menyelenggarakan pendidikan dapat dilihat dari berbagai hal, salah satunya adalah dalam hal prestasi belajar yang diperoleh oleh anak. Prestasi belajar adalah suatu bukti keberhasilan belajar atau kemampuan seorang anak dalam melakukan kegiatan belajarnya sesuai dengan bobot yang dicapainya. Minat belajar seorang anak 
dapat menjadi gambaran berhasil tidaknya suatu proses pembelajaran yang telah dilakukan. Prestasi belajar dipengaruhi oleh proses belajar anak yang akan menentukan tingkat minat belajar anak.

Minat belajar anak secara garis besar dipengaruhi oleh dua faktor yaitu faktor internal dan faktor eksternal. Faktor-faktor internal yang berasal dari dalam diri anak meliputi: faktor jasmaniah (terdiri dari faktor kesehatan dan cacat tubuh), faktor psikologi (terdiri atas intelegensi, perhatian, minat, bakat, motivasi, persepsi, kematangan dan kesiapan) dan faktor kelelahan. Sedangkan faktor eksternal yang berasal dari luar diri anak meliputi: faktor keluarga yaitu cara orang tua mendidik, relasi antar anggota keluarga, suasana rumah, keadaan ekonomi keluarga, pengertian orang tua, latar belakang kebudayaan, faktor sekolah yaitu metode mengajar, kurikulum, hubungan guru dengan anak, hubungan anak dengan anak, disiplin sekolah, alat pelajaran, waktu sekolah, keadaan gedung, metode belajar dan tugas rumah; faktor masyarakat yaitu kegiatan anak dalam masyarakat, media, teman bergaul, dan bentuk kehidupan masyarakat. Kecerdasan berasal dari kata cerdas yang berarti pintar dan cerdik, cepat tanggap dalam menghadapi masalah dan cepat mengerti jika mendengar keterangan. Kecerdasan adalah kesempurnaan perkembangan akal budi (Dalyono, 2018).

\section{Generasi Berjiwa Qur'ani}

Generasi Qur'ani adalah generasi yang menjiwai dan mengamalkan AlQur'an, sebagai kitab Allah yang sempurna, juga sebagai penyempurna kitab-kitab sebelumnya. Tidak ada penambahan atau pengurangan dalam Al-Qur'an. Dengan AlQur'an ini pula Rasulullah berhasil mencetak sebuah umat yang kuat aqidahnya, 
benar ibadahnya, dan bagus akhlaknya. Inilah generasi qur'ani. Generasi qur'ani / ahul qur'an adalah orang yang selalu mendapat ketenangan, rahmat, dan naungan malaikat dan penyebutan namanya oleh allah SWT dihadapan malaikat-Nya. Generasi yang berjiwa qur'ani berarti generasi yang memiliki kepribadian qur'ani, yaitu kepribadian yang (personality) yang dibentuk dengan susunan sifat-sifat yang sengaja diambil dari nilai-nilai yang diajarkan Allah SWT dalam Al-Qur'an, sehingga bisa dibayangkan strukturnya terbangun dari elemen-elemen ajaran Al-Qur'an itu (Nawawi, 2014).

Mencetak berarti menghasilkan sesuatu dengan usaha-usaha tertentu. Mencetak yang dimaksudkan disini adalah menghasilkan generasi dengan usahausaha tertentu seperti mendidik, mengarahkan, membimbing, membina manusia untuk memiliki jiwa qur'ani. Membicarakan tentang manusia, makhluk berjiwa, berkepribadian, dan berhati nurani, selalu menarik. Oleh karena itu, baik pembicaraan mengenai aspek luar (fisik) maupun aspek dalam dari diri manusia, seperti jiwa dan hati, tidak pernah selesai (Rauf, 2015; Nawawi, 2014).

Al-Qur'an telah menjadi saksi bagi nilai utama dari ilmu pengetahuan. Ayat yang pertama turun merupakan awal pembebasan buta huruf, peningkatan apresiasi terhadap ilmu pengetahuan, dan pengenalan tentang hakikat kebenaran dalam kehidupan umat manusia. Allah SWT mengajarkan sesuatu yang belum manusia ketahui, mengeluarkan dari kegelapan, kebodohan, dan mengarahkan kepada cahaya ilmu pengetahuan dan teknologi serta membuat umat manusia sadar akan rahmat yang tak ternilai harganya yaitu pengetahuan yang darinya dinamika ilmu berjalan dan menyentuh segala sisi kehidupan (Roqib, 2009). 
Dengan demikian, tidak dapat dipungkiri bahwa segala macam ilmu pengetahuan berasal dari kitab suci Al-Qur'an. Sebab itu, sangat penting mendidik manusia dengan pendidikan agama yang bermuara pada kalamullah. Barulah setelah itu dapat mencetak generasi yang betul-betul Qur'ani, yaitu masyarakat yang anggotanya terdiri dari orang-orang yang merupakan penjelmaan Al-Quran dalam setiap gerak kehidupannya. Masyarakat yang diasuh dan dibimbing dengan arahan AlQuran, hidup di bawah naungannya, dan berjalan di bawah cahayanya. Bahkan memahami Al-Qur'an adalah wajib berdasarkan ayat berikut: "Maka mengapakah mereka tidak mau mentadabburi al-Qur'an? Apakah karena hati mereka terkunci mati?" (Rouf: 2015).

Rasulullah SAW bersabda: “Siapa yang mempelajari al-Qur'an ketika masih muda, maka al-Quran itu akan menyatu dengan daging dan darahnya. Siapa yang mempelajarinya ketika dewasa, sedangkan ilmu itu akan lepas darinya dan tidak melekat pada dirinya, maka ia mendapatkan pahala dua kali”. (HR al-Baihaqi, adDailami, dan al-Hakim).

\section{Pengertian Pendidikan Agama Islam}

Dalam konteks Islam, istilah pendidikan mengacu kepada makna dan asal kata yang membentuk kata pendidikan itu sendiri dalam hubungannya dengan ajaran Islam. Maka pada konteks ini, perlu juga dikaji hakikat pendidikan Islam yang didasarkan pada sejumlah istilah yang umum dikenal dan digunakan para ahli pendidikan Islam. Ada tiga istilah yang umum digunakan dalam pendidikan Islam, yaitu: al-tarbiyah, al-ta'lim, dan al-ta'dib. Setiap istilah tersebut mempunyai makna yang berbeda karena perbedaan teks dan konteks kalimatnya. Walaupun dalam hal-hal 
tertentu istilah-istilah tersebut juga memiliki kesamaan makna (Salim \& Kurniawan, 2012).

Sesungguhnya, bila dicermati pemaknaan dari masing-masing istilah, baik altarbiyah, al-ta'lim, maupun al-ta'dib, semuanya merujuk kepada Allah. Tarbiyah yang diterangai sebagai kata bentukan dari kata rabb/rabba mengacu kepada Allah sebagai Rabb al-'alamin. Sementara ta'lim yang berasal dari kata 'allama, juga merujuk kepada Allah sebagai dzat yang maha 'alim. Selanjutnya, kata ta'dib seperti termuat dalam sabda Rasulullah Saw., “Addabani Rabbi Faahsana Ta'dibi”, memperjelas bahwa sumber utama pendidikan adalah Allah. rasul sendiri menegaskan bahwa beliau dididik oleh Allah sehingga pendidikan yang beliau peroleh adalah sebaik-baik pendidikan. Oleh karenanya Rasulullah Saw. merupakan pendidik utama yang harus dijadikan teladan (Salim \& Kurniawan, 2012).

Berdasarkan atas pengertian al-tarbiyah, al ta'lim, dan al-ta'dib diatas, para ahli pendidikan Islam juga mencoba memformulasikan hakikat pendidikan Islam, dan seperti pemaknaan istilah pendidikan, formulasi hakikat pendidikan Islam ini juga berbeda satu sama lain. Inilah beberapa diantara formulasi tersebut:

1. Muhammad Fadlil Al-Jamaly memberikan arti pendidikan islam dengan upaya mengembangkan, mendorong, serta mengajak manusia lebih maju dengan berlandaskan nilai-nilai yang tinggi, dan kehidupan yang mulia sehingga terbentuk pribadi yang lebih sempurna, baik yang berkaitan dengan akal, perasaan, maupun perbuatan.

2. Omar Muhammad Al-Toumy Al-Syaebani mendefinisikan pendiikan Islam sebagai usaha mengubah tingkah laku dalam kehidupan, baik individu maupun 
bermasayarakat serta berinteraksi dengan alam sekitar melalui proses kependidikan berlandaskan nilai Islam.

3. Muhammad Munir Mursyi mengatakan bahwa pendidikan Islam adalah pendidikan fitrah manusia. Disebabkan Islam adalah fitrah maka segala perintah, larangan, dan kepatuhannya dapat mengantarkan mengetahui fitrah ini.

4. Hasan Langgulung mendefinisikan pendidikan islam sebagai proses spiritual, akhlak, intelektual, dan sosial yang berusaha membimbing manusia dan memberiya nilai-nilai, prinsip-prinsip, dan teladan ideal, dalam kehidupan yang bertujuan mempersiapkan kehidupan dunia akhirat.

Pendidikan Agama Islam merupakan pendidikan yang secara khas memiliki ciri Islami, berbeda dengan konsep pendidikan Islam yang kajiannya lebih memfokuskan pada pemberdayaan umat berdasarkan Al-Qur'an dan hadits. Artinya kajian pendidikan islam bukan sekedar menyangkut aspek normatif ajaran Islam, tetapi juga terapannya dalam ragam materi, institusi, budaya, nilai, dan dampaknya terhadap pemberdayaan umat (Minarti, 2013).

M. Kamal Hasan sebagaimana dikutip Taufiq Abdullah dan Sharon Shiddique, memberiikan pengertian bahwa pendidikan Agama Islam adalah suatu proses komprehensif dari pengembangan kepribadian manusia secara keseluruhan yang meliputi intelektual, spiritual, emosi, dan fisik. Dengan demikian, seorang muslim disiapkan dengan baik untuk melakukan tugasnya sebagai hamba dan wakil Tuhan di muka bumi.

Pendidikan Agama Islam adalah segala upaya atau proses pendidikan yang dilakukan untuk membimbing tingkah laku manusia, baik individu maupun sosial 
untuk mengarahkan potensi, baikpotensi dasar (fithrah), maupun ajar yang sesuai dengan fitrahnya melalui proses intelektual dan spiritual berlandaskan nilai Islam untuk mencapai kebahagiaan hidup di dunia dan akhirat (Salim \& Kurniawan, 2012).

Dari berbagai pengertian di atas, dapat disimpulkan bahwa pendidikan agama Islam adalah rangkaian proses sistematis, terencana, dan komprehensif, dalam upaya mentransfer nilai-niai kepada para peserta didik serta megembangkan potensi yang ada pada diri mereka sehingga mampu melaksanakan tugasnya di muka bumi dengan sebaik-baiknya sesuai dengan nilai-nilai Ilahiyyah yang didasarkan pada Al-Qur'an dan hadits di semua dimensi kehidupan.

\section{Tujuan Pendidikan Agama Islam}

Berbicara tentang tujuan pendidikan, erat kaitannya dengan tujuan kehidupan manusia. Hal itu disebabkan pendidikan merupakan alat yang digunakan manusia untuk memelihara kelanjutan hidupnya, baik sebagai individu maupun masyarakat. Oleh karena itu, tujuan pendidikan harus diarahkan sesuai dengan kebutuhan yang sedang dihadapi. Seperti yang diungkapkan oleh Muhammad Athiyah Al-Abrasyi, bahwa tujuan utama dari pendidikan Islam adalah pembentukan akhlak dan budi pekerti yang sanggup menghasilkan orang-orang yang bermoral, berjiwa bersih, pantang menyerah, bercita-cita tinggi, dan berakhlak mulia, baik laki-laki maupun perempuan. Selain itu juga mengerti kewajiban masing-masing, dapat membedakan antara baik dan buruk, mampu menyusun skala prioritas, menghindari perbuatan tercela, mengingat tuhan, dan mengetahui setiap pekerjaan apa yang dilakukan (Salim \& Kurniawan, 2012).

Menurut pandangan Islam, tujuan pendidikan Islam sangat diwarnai dan dijiwai oleh nilai-nilai ajaran Allah. tujuan itu sangat dilandasi oleh nilai-nilai Al- 
Qur'an dan hadits seperti yang termaktub dalam rumusan, yaitu menciptakan pribadipribadi yang selalu bertakwa kepada Allah, sekaligus mencapai kebahagiaan di dunia dan akhirat. Dalam First World Conference on Muslim Education yang diadakan di Mekkah pada tahun 1977 telah menghasilkan rumusan yang menyatakan bahwa tujuan pendidikan islam yaitu mencapai pertumbuhan kepribadian manusia yang menyeluruh secara seimbang melalui latihan jiwa, intelek, perasaan,dan indra (Salim \& Kurniawan, 2012).

Sementara tujuan pendidikan Islam yang paling tinggi adalah tujuan hidup seorang muslim itu sendiri. Sementara tujuan hidup seorang muslim adalah pengabdian kepada Allah (Shihab, 2002).

Allah SWT berfirman:

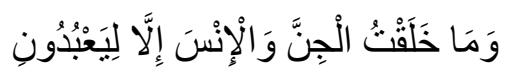

"Dan aku tidak menciptakan jin dan manusia melainkan agar beribadah kepada-ku" (QS. Al-Dzariyat [51]:56)

Tujuan pendidikan Islam adalah terbentuknya kepribadian muslim. sementara menurut Al-Attas, tujuan pendidikan Islam adalah tercapainya manusia yang baik. Dari beberapa pendapat tersebut, tampaknya masih bersifat umum. Secara rinci, tujuan khusus Pendidikan Agama Islam, antara lain (Salim \& Kurniawan, 2012; Shihab, 2002):

1. Memperkenalkan kepadapeserta didik dasar-dasar akidah Islam, ibadah, dan tata cara pelaksanaannya dengan betul. Dengan membiasakan peserta didik untuk hati-hati dan mentaati syariat agama.

2. Menumbuhkan kesadaran agama yang benar pada diri peserta didik, serta menghindar dari bid'ah dan khurafat yangkurang disadari keberadaannya. 
3. Menanamkan keimanan dan prinsip-prinsipnya kepada jiwa peserta didik.

4. Menumbuhkan minat peserta didik untuk menambah pengetahuan dengan penuh kesadaran dan kerelaan.

5. Menanamkan kepada peserta didik rasa cinta dan penghargaan terhadap AlQur'an melalui membaca, memahami, dan mengamalkan isi kandungannya.

6. Menumbuhkan rasa kebanggaan terhadap sejarah dan kebudayaan Islam untuk mengikuti jejak keberhasilan yang dicapai pendahulunya.

7. Menumbuhkan sifat keikhlasan, optimis, percaya diri, tanggung jawab, menghargai kewajiban, tolong menolong dalam kebajikan, kasih sayang, cinta kebaikan, sabar, dan berpegang teguh pada prinsip.

8. Mendidik naluri, motivasi, dan keinginan anak yang dibentengi dengan akidah dan nilai positif, serta membiasakan untuk menahan emosi dalam bergaul.

9. Menyuburkan hati anak didik dengan mahabbah, dzikir, dan takwa.

10. Membersihkan hati anak didik dari sifat tercela, seperti dengki, hasad, benci, kekerasan, ego, khianat, nifaq, bimbang, dan lain sebagainya.

Jika dicermati lebih lanjut, akan terlihat bahwa tujuan pendidikan islam tidaklah bertentangan dengan tujuan pendidikan nasional bangsa Indonesia, seperti tertulis dalam pasal 4 UU RI Nomor 20 tahun 2003 tentang Sistem Pendidikan Nasional, yang berbunyi (Salim \& Kurniawan, 2012; Shihab, 2002):

"Pendidikan Nasional bertujuan untuk berkembangnya potensi peserta didik agar menjadi manusia yang beriman, bertakwa kepada Tuhan Yang Maha Esa, berkahlak mulia, sehat, berilmu, cakap, kreatif, mandiri, dan menjadi warga Negara yang demokratis, dan bertanggung jawab." 
Dari penjelasan di atas tampak bahwa pendidikan moral adalah jiwa dari pendidikan Islam. Mencapai suatu akhlak yang sempurna adalah tujuan yang sebenarnya dari pendidikan dalam pandangan Al-Qur'an. Artinya pendidikan agama Islam berhasil manakala berhasil mencetak generasi berjiwa qur'ani. Hal ini sejalan dengan misi yang dibawa oleh Rasulullah seperti dijelaskan dalam sebuah hadis: "Sesungguhnya saya diutus hanya untuk menyempurnakan moral yang mulia". Sedangkan sasaran penyempurnaan akhlak itu sendiri adalah umat manusia di muka bumi ini.

\section{Dasar-dasar Pendidikan Agama Islam}

Dasar pendidikan Islam, secara garis besar ada tiga, yaitu Al-Qur'an, sunnah, dan perundang-undangan yang berlaku di Negara kita. Sementara, para pemikir muslim membagi sumber/dasar nilai ideal yang dijadikan acuan dalam pendidikan Islam menjadi empat bagian, yaitu: Al-Qur'an, sunnah (hadits), alam semesta, dan ijtihad (Minarti, 2013).

Al-Qur'an merupakan kitab suci terakhir yang diwahyukan Allah kepada Nabi Muhammad untuk dijadikan pedoman umat manusia. Al-Qur'an merupakan sumber pendidikan terlengkap yang menyangkut kemasyarakatan (sosial), moral (akhlak), spiritual (kerohanian), material (kejasmanian), dan alam semesta. Al-Qur'an merupakan sumber nilai yang absolut dan utuh. Eksistensinya tidak akan pernah mengalami perubahan. Al-Qur'an merupakan pedoman normatif-teoritis yang masih memerlukan penafsiran lebih lanjut terhadap pelaksanaan operasional pendidikan Islam. Al-Qur'an tidak begitu saja dapat mengubah dunia tanpa adanya usaha untuk mengimplementasikannya. Dibutuhkan penafsiran untuk menggali semua ajaran yang 
terkandung di dalamnya. Dengan demikian, agar manusia dapat menemukan jati dirinya sebagai insan yang bermartabat, maka harus menyelenggarakan pendidikan.

Ketika merujuk pada sumber utama agama Islam, yaitu Al-Qur'an, maka akan ditemukan pernyataan bahwa Nabi Muhammad merupakan uswah hasanah yang paling utama bagi umatnya yang benar-benar beriman kepada Allah dan kehidupan akhirat.

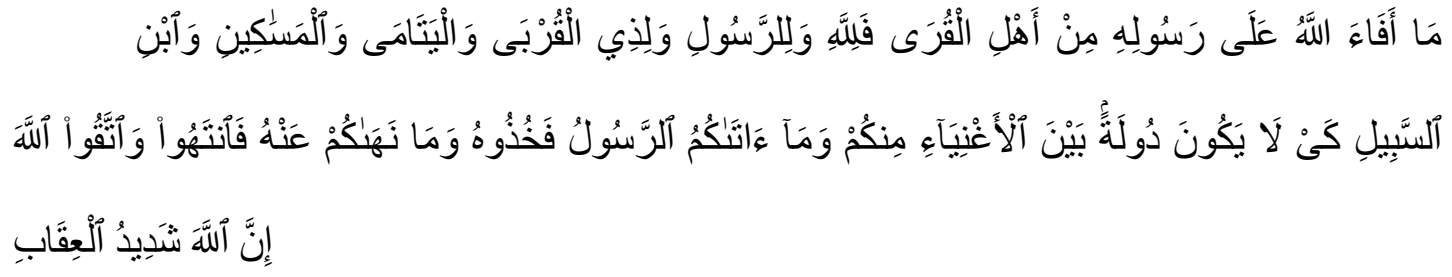

Artinya: "apa saja harta rampasan yang diberikan Allah kepada Rosulnya, yang berasal dari penduduk kota-kota maka untuk Allah, kerabat Rosul, anak-anak yatim, orang-orang miskin, dan orang-orang yang dalam perjalanan supaya harta itu jangan beredar diantara orang-orang kaya saja diantara kamu. Apa yang diberikan Rasul kepadamu, maka terimalah dia. Dan apa yang dilarangnya bagimu, maka tinggalkanlah dan bertakwalah kepada Allah. sesungguhnya Allah sangat keras hukumannya (Shihab, 2002).

Ayat tersebut dapat dilihat dengan jelas bahwa kedudukan hadits merupakan dasar utama yang dapat dipergunakan sebagai acuan bagi pelaksanaan pendidikan Islam yang dapat ditiru dan dijadikan referensi teoritis dan praktis (Minarti, 2013).

Para penganut paham materialisme meyakini bahwa alam semesta itu tidak berharga. Namun ilmu pengetahuan dan teknologi yang berkembang pada abad XX akhirnya melumpuhkan gagasan kuno yang dinamakan materialisme ini. Telah ditemukan fakta bahwa alam semesta tidaklah tetap seperti dugaan paham materialisme, tetapi justru sebaliknya, alam semesta terus berkembang. Kini fakta ini 
telah diterima diseluruh dunia ilmu pengetahuan dan bahkan menjadi suatu aksioma bagi landasan ilmu pengetahuan masa depan.

Ijtihad secara bahasa berarti berusaha secara sungguh-sungguh. Sementara itu, Umar Shihab mendefinisikan ijtihad dengan kesulitan atau kesusahan. Lebih lanjut, ia mendefinisikan ijtihad dengan segala daya dan upaya yang mengarah pada pengkajian, baik pengkajian dalam ilmu hukum, ilmu kalam, maupun ilmu tasawuf. Semuanya itu dikategorikan sebagai ijtihad. Dengan demikian, orang yang terjun dalam pengkajian itu disebut mujtahid. Seiring dengan perkembangan zaman yang semakin mengglobal dan mendesak, ijtihad dalam bidang pendidikan mutlak diperlukan. Sasarannya tidak hanya sebatas bidang materi, kurikulum, metode, evaluasi, sarana, dan prasarana, tetapi mencakup seluruh sistem pendidikan Islam. Hal ini dikarenakan pendidikan merupakan sarana utama untuk membangun pranata kehidupan sosial dan kebudayaan manusia.

\section{Mencetak Anak Usia Dini Yang Berjiwa Qur'ani dalam perspektif Pendidikan}

\section{Agama Islam}

Untuk mewujudkan tujuan pendidikan Islam, maka dibutuhkan generasigenerasi yang mampu mencintai, menjaga, serta mengamalkan Al-Qur'an dalam setiap aspek kehidupan sejak usia dini, yakni generasi usia dini yang berjiwa Qur'ani. Maka berikut adalah cara mencetak generasi yang berjiwa Qur'ani, yakni sebagai berikut (Rauf, 2015):

1. Memahami hakikat kalam Allah SWT

Langkah ini sangat penting sebagai langkah awal merasakan keagungan AlQur'an. Dalam arti, bagaimana mungkin kita akan merasakan betapa mahalnya suatu 
benda, emas misalnya, jika kita tidak mengetahui nilai dan harga emas. Oleh karena itu Allah mengecam manusia yang tidak berusaha memahami Al-Qur'an. Di dalam surat Al Baqarah [2]:78, disebut sebagai manusia yang buta huruf:

2. Merasakan keagungan Al-Qur'an

Perasaan mengagungkan Al-Qur'an adalah sebagai dampak ma'rifah seorang hamba kepada Allah SWT Sang Khaliq sebagai penguasa alam semesta. Oleh karena itu, mengenal Allah mutlak harus dibangun sebelum berinteraksi dengan Al-Qur'an. Sarananya adalah dengan mengkaji Al-Qur'an, As sunnah, dan bertafakkur terhadap alam semesta. Karena kemampuan mengagungkan Al Mutakallim (yang berfirman, Allah) akan menghasilkan pengagungan terhadap kalam-Nya.

3. Melibatkan hati saat bersama Al-Qur'an

Melibatkan hati artinya memfokuskan hati hanya untuk Al-Qur'an dan melepaskan segala perasaan lain yang menjadikan hati tersibukkan oleh selain AlQur'an seperti urusan dunia. Oleh karena itu generasi terdahulu (salafush shalih) saat membaca Al-Qur'an, jika terasa hambar saat membaca suatu ayat, mereka mengulang-ngulangnya sampai hatinya merasakan benar apa yang dipesankan oleh Allah dalam ayat tersebut (Rauf, 2015).

4. Merenungi dan menghayati ayat-ayat-Nya (At-Tadabbur)

Mentadabburi berarti berupaya memahami pesan-pesan yang terkandung dalam ayat yang sedang kita baca atau kita dengar, sehingga akan terasa luasnya makna dan keagungan satu ayat yang difirmankan Allah. Inilah rahasia mengapa Rosulullah SAW sering mengulang-ulang satu ayat sampai berpuluh-puluh kali, karea saat itu Rosulullah SAW sedang melakukan tadabbur satu ayat dan merasakan luasnya pesan-pesan Al-Qur'an (Rauf, 2015). 
5. Segera menyadari jika tidak paham suatu ayat, dan segera memahami (attafahhum)

At-tafahhum bisa terkait dengan kalimat, ayat, atau tafsir dari ayat yang sedang kita baca. Berkomitmen dengan cara ini sepanjang kita berinteraksi dengan Al-Qur'an, Insya Allah akan menjadikan kita memahami seluruh kandungan AlQur'an. ${ }^{1}$

6. Membersihkan diri dari faktor-faktor penghalang memahami Al-Qur'an

Kemaksiatan, sedikit beramal shalih, cinta dunia secara berlebihan, dan malas mengkaji ayat-ayat Allah, adalah diantara faktor yang dapat menyebabkan kita tercegah dari semangat memahami Al-Qur'an. memahami Al-Qur'an terdiri dari pemahaman yang bersumber dari akal dan hati. Pemahaman dari dua unsur ini akan menghaislkan hidayah yang terus berkembang dalam diri manusia (Rauf, 2015).

7. Merasakan bahwa pesan ayat yang dibaca, dikhususkan untuk dirinya (AtTakhsis)

Muhammad Bin Ka'ab Al-Quradzi mengatakan:“siapa yang sampai kepadanya ayat-ayat Al-Qur'an, maka sesungguhnya Allah SWT sedang menasehatinya." Ulama' yang lain mengatakan “Al-Qur'an adalah surat yang datang dari Allah, kami tadabburi Al-Qur'an pada waktu shalat, dan mengkajinya pada waktu luang, serta mengamalkannya dalam ketaatan.” Dengan At-Takhsis setiap kali membaca ayat, maka kita harus merasakan bahwa yang dimaksud oleh yat tersebut adalah diri kita, walaupun ayat tersebut lafadznya umum, seperti:"wahai orang-orang yang beriman", maka sejatinya, diri kita yang dimaksud (Rauf, 2015).

\footnotetext{
${ }^{1}$ Ibid, h.68.
} 
8. Berusaha reaktif sesuai dengan kandungan ayatnya (At-ta'atsur)

Seorang pembaca Al-Qur'an harus dapat merasakan perasaan yang berbedabeda sesuai dengan kandungan ayat yang sedang dibaca. Misalnya, ketika dibaca ayat Allah memerintahkan ibadah, bersujud, berinfaq, dan seterusnya, maka ia harus dapat membuat kita langsung bereaksi, mengikuti kandungan ayat yang kita baca. Imam Hasan Al Bashri pernah mengatakan, "Demi Allah, tidaklah seorang hamba pada pagi hari membaca Al-Qur'andengan sebaik-baiknya dan beriman kepadanya, kecuali akan banyak sedih,sedikit gembiranya, banyak tangisnya, sedikit tertawanya, banyak bekerjanya, dan sedikit santainya".

9. Berusaha merasakan peningkatan ruhnya lebih dekat bersama Al-Qur'an (AtTaraqqi)

Pantaslah jika membaca Al-Qur'an disebut sebagai bentuk dzikir kepada Allah yang terbaik. Jika Ahli Tasawwuf merasakan taraqqi dengan bacaan tahlilnya, sehingga akan menghasilkan At-Ta'atsur manusia dalam membaca Al-Qur'an ada tiga tingkatan sebagai berikut (Rauf, 2015):

a. Seorang yang membaca Al-Qur'an dengan perasaan seakan-akan ia menghadap Allah dan penuh pengharapan kepadan-Nya.

b. Seorang yang membaca Al-Qur'an dengan perasaan hatinya seakan-akan sedang menghadap Allah dan dia menyambut dan memperhatikannya.

c. Seseorang yang membaca A Qur'an dengan perasaan larut bersama ayatayatnya dengan segenap hati dan pikirannya sehingga ia tidak lagi memikirkan dirinya dan kuantitas bacaannya. Inilah tilawah muqarrabin (orang-orang yang dekat dengan Allah). 
10. Tidak merasa diri sebagai manusia yang paling suci (At-tabarri)

Adalah Abdullah Bin Umar bin Khattab ketika membaca ayat-ayat yang menjelaskan sifat manusia yang negatif, ia segera banyak beristighfar, "Ya Allah, aku mohon ampun kepada-Mu dari kedzaliman dan kekufuranku” (Rauf, 2015).

Sepuluh kiat itulah cara mencetak generasi yang berjiwa Qur'ani dalam buku berjudul Tarbiyah Syakhsiyah Qur'aniyah karya Abdur Aziz Abdur Rauf yang akan kita biasakan pada anak usia dini, dengan membiasakan dalam mencintai, menjaga, serta mengamalkan Al-Qur'an dalam setiap aspek kehidupan sejak usia dini. Dengan adanya bentuk-bentuk interaksi anak usia dini dengan Al-Qur'an diharapkan sejak usia dini anak dapat menjadi generasi Qur'ani yang mencintai Al-Qur'an.

\section{KESIMPULAN}

Generasi Qur'ani adalah generasi yang menjaga ayat-ayat allah dihatinya, yang memiliki kepribadian Qur'ani, yang mengambil Al-Qur'an sebagai sumber utama kehidupannya, dengan membaca, mempelajari, memahami dan mengamalkan AlQur'an dalam setiap aspek kehidupan.

Adapun mencetak generasi anak usia dini yang berjiwa Qur'ani dalam perspektif Pendidikan Agama Islam yaitu dengan membangun kepribadian Qur'ani di usia sedini mungkin dengan cara antara lain: membangun rasa cinta pada AlQur'an, Memperdengarkan lantunan Al-Qur'an one day one juz, melaksanakan kewajiban pada Al-Qur'an, banyak berdoa kepada Allah, menumbuhkan mujahadah takwa kepada Allah, tadabbur Al-Qur'an, mengatasi rasa malas berinteraksi dengan Al-Quran, serta menyampaikan isi Al-Qur'an. 


\section{REFERENSI}

Abdur Aziz Abdur Rouf Al Hafidz, Tarbiyah Syakhsiyah Qur'aniyah cet ke-4, (Jakarta: Markaz Al-Qur'an, 2015).

Dalyono. Belajar dan Faktor-Faktor yang Mempengaruhinya. (Jakarta: PT Rineka Cipta, 2018).

Daryanto, Kamus Bahasa Indonesia Lengkap, (Surabaya:Apollo,1997).

M. Quraish Shihab, Tafsir Al Mishbah, (Jakarta: Lentera Hati, 2002).

Moh. Haitami Salim dan Syamsul Kurniawan, Studi Ilmu Pendidikan Islam, (Jogjakarta: Ar-Ruzz Media, 2012).

Muh. Roqib, Ilmu Pendidikan Islam, Pengembangan Pendidikan Integratif Di Sekolah, Keluarga, Dan Masyarakat, (Yogyakarta: LKIS Printing Cemerlang, 2009).

Muijs, Daniel, \& Reynolds, David. Effective teaching: Teori dan Aplikasi. (Yogyakarta: Pustaka Pelajar, 2017).

Rif'at Syauqi Nawawi, Kepribadian Qur'ani, (Jakarta: Amzah, 2014).

Sri Minarti, Ilmu Pendidikan Islam, ( Jakarta: Amzah, 2013).

Suprijanto. Pendidikan Orang Dewasa: Dari Teori Hingga Aplikasi.(Jakarta: PT Bumi Aksara, 2015). 